DOI: $10.31393 /$ reports-vnmedical-2021-25(3)-17

UDC: $616.53-008.811 .1-037-084-036.1: 616-071.2$

\title{
CLINICAL AND ANAMNESTIC FEATURES OF MEN AND WOMEN WITH GENERALIZED FATTYY FORM OF SEBORRHEIC DERMATITIS OF VARYING SEVERITY
}

\section{Khasawneh Ahmad Raed}

National Pirogov Memorial Medical University, Vinnytsya (Pyrogov street, 56, Vinnytsya, Ukraine, 21018)

Responsible for correspondence: e-mail:drahmad khasawneh@yahoo.com

Received: June, 22, 2021; Accepted: July, 28, 2021

Annotation. Despite the prevalence of seborrheic dermatitis (SD), especially among young people, little is known about its clinical and anamnestic features in the population of Ukraine. To fill this gap, it is necessary to conduct a study of reliable data obtained from the domestic sample of working age. The aim of the study is to find the clinical and anamnestic features of men and women with generalized fatty form of seborrheic dermatitis of varying severity. A survey of 40 men and 40 young women (25-44 years according to the age periodization of the WHO, 2015) in patients with generalized fatty seborrheic dermatitis was conducted on the basis of the Department of Skin and Venereal Diseases with a postgraduate course in National Pirogov Memorial Medical University, Vinnytsya and the Military Medical Clinical Center of the Central Region. Retrospective analysis included assessment of passport, anamnestic, clinical data. Diagnosis of SD was established on the basis of complaints of the subject, life history and illness, examination of the face, scalp, torso and extremities with the assessment of subjective and objective signs of the disease. Statistical analysis was performed using the license package "Statistica 6.0". It was found that the severity of SD increased with increasing length of service and depended on the type of professional activity. Stress, temperature, humidity, smoking, heredity caused the manifestation or exacerbation of dermatosis. Acne and rosacea often accompanied severe SD. Itching and oiliness of the skin, rash on the head and face, erythematous spots and plaques, the predominance of red dermographism were observed in both types of flow, and the feeling of dirt, localization of pathological elements on the body, sebaceous scales - only in severe. Thus, the data obtained in our study can form the basis for the development of an algorithm for monitoring patients with generalized seborrheic dermatitis of varying severity. Keywords: seborrheic dermatitis, generalized form, clinical and anamnestic data, men, women, risk factors.

\section{Introduction}

The problem of generalized oily form of seborrheic dermatitis (SD) is one of the current topics in modern dermatology. Despite progress in health care, the incidence of this disease has not decreased in recent years, and in some countries even increases [15]. According to the World Health Organization, the prevalence of SD in the adult population ranges from 1 to 5 percent, dermatosis develops regardless of ethnicity and seems to affect men more often than women. After 50 years, the incidence of both sexes is almost the same [4, 14].

SD can appear first during puberty, correlating with an increase in skin lipids due to the intensive development of sebaceous glands caused by androgens, and the secretion of sebum. The course of SD in adults varies throughout adulthood, with some patients experiencing only infrequent periods of exacerbation, while others have a spread (generalization) of the pathological process with more frequent relapses $[8,11,18]$.

Although this disease is multifactorial, there are three main factors that are more likely to play a role in its development: sebaceous gland secretion, changes in colonization and metabolism of skin microflora, individual susceptibility and patient response. Currently, all known factors (socio-hygienic, clinical and anamnestic) allow to distinguish a high-risk group for SD. However, so far little has been studied that serves as the initiator of the disease, and it is not clear how to predict recurrence, generalization or torpid course of the skin process [3, 9, 13].

Despite the prevalence of SD, especially among young people, little is known about its clinical and anamnestic features in the population of Ukraine. To fill this gap, it is necessary to conduct a study of reliable data obtained from the domestic sample of working age. This, in turn, will prevent significant economic costs, both direct (doctor's visits, pharmacological costs) and indirect (loss of training hours and professional productivity), and will preserve the mental and physical health of patients.

The aim of the study was to study the clinical and anamnestic features of men and women with generalized fatty form of seborrheic dermatitis of varying severity.

\section{Materials and methods}

In accordance with this goal, a survey of 40 men and 40 young women (25-44 years according to the age periodization of the $\mathrm{WHO}, 2015)$ patients with generalized oily seborrheic dermatitis at the Department of Dermatology and Venereal Diseases with a postgraduate course in National Pirogov Memorial Medical University, Vinnytsya and the Military Medical Clinical Center of the Central Region done. Retrospective analysis included assessment of passport, anamnestic, clinical data.

The diagnosis of SD was established on the basis of the subject's complaints, life history and illness, examination of the face, scalp, torso and limbs with the 
assessment of subjective and objective signs of the disease. Criteria for inclusion of the patient in the study: the presence of SD in men and women aged 25 to 44 years, signed an informed consent to participate in the study. Criteria for exclusion of the patient from the study: concomitant pathology in the acute stage, liver failure, chronic kidney disease, malignancies, malabsorption syndrome, chronic alcoholism, mental illness, primary hyperparathyroidism, hypersensitivity to UV rays, lactation, pregnancy and other drugs vitamin D metabolism, excessive physical and emotional overload, night work, therapy for the last 3 months with corticosteroids, antifungal, antiepileptic and vitamin drugs, a positive HIV test.

Statistical analysis was performed using the license package "Statistica 6.0".

\section{Results. Discussion}

The severity of skin manifestations in SD is individual and variable, but it has been proven that it depends on the duration and severity of the disease [13]. The duration of the disease in our subjects ranged from several months to 21 years. The largest group of subjects with mild SD were patients with disease duration at the time of the study from 1 to 3 years (18 men - $90 \%$ ) and from 2 to 4 years (14 women - $70 \%$ ), among whom men predominated. Patients with severe dermatosis and disease duration from 2 to 5 years accounted for a fairly large percentage (14 men - 70 $\%$ and 13 women - $65 \%$ ). The age of all patients was 2544 years, ie it was a socially active, able-bodied group.

With heavy physical and mental work, the excitement of sebium secretion increases even more, which can be a trigger in the formation of seborrheic rashes [6]. Among the possible causes of the onset of the disease, an assessment of the nature of work in subjects with varying severity of SD. Among men with mild dermatosis, subjects with physical nature of labor predominated (13 men - 65 $\%$, and with severe course - with physical and mixed (respectively 16 men - $75 \%$ ). In women, regardless of the severity of the disease was dominated by persons whose professional activities are mental and mixed (respectively, 19 women with mild and severe course, which amounted to $95 \%$ ).

The processes of allergy and SD are interrelated. This is because the hormonal imbalance that underlies SD provokes immune disorders, such as hypersensitivity to dietary proteins. When the allergen is absorbed in the intestinal mucosa, inflammation occurs, resulting in toxins (breakdown products) entering the bloodstream. With the bloodstream, these substances are sent to the subcutaneous fat, where they also cause inflammation. The result is atopic dermatitis (itching and rash without direct skin/allergen contact). In turn, local inflammation, itching provoke SD: the period of exacerbation is prolonged, the separation of sebum increases, the risk of skin infection increases $[5,6]$.

In patients with SD, we determined the presence of allergic reactions, and only a small percentage (5\%) of the studied men and women, regardless of the severity of SD had allergic reactions.

The exact cause of SD is unknown. It is assumed that there is a genetic predisposition to this disease. The development of seborrhea can be provoked by emotional experiences, stress, autonomic dystonia. In addition, an important role is played by endocrine disorders associated with an imbalance of female and male sex hormones. Symptoms of seborrhea may be exacerbated by eating spicy, salty and sweet foods, as well as under certain weather conditions (low humidity, insolation). Contact with chemicals, deficiency of B vitamins, food allergies, bad habits play a role [1,7].

In the vast majority of patients with mild and severe dermatosis, the presence of factors influencing its manifestation or exacerbation (19 men from each group $95 \% ; 17$ and 20 women from each group - $95 \%$ and $100 \%$, respectively).

Among the causes of exacerbation of dermatosis noted: stress - in 8 men with mild (40\%) and 10 with severe $(50 \%)$, in 6 women with mild $(30 \%)$ and 8 with severe (40\%);

temperature factor - in 12 men with mild (60\%) and 10 with severe $(50 \%), 10$ women with mild (50\%) and 18 with severe $(90 \%)$;

seasonality - in 3 men with mild (15\%) and 7 with severe (35\%), 4 women with mild (20\%) and 4 with severe (20\%); humidity - in 12 men with mild (60\%) and 6 with severe (30\%), 8 women with mild (40\%) and 9 with severe (45\%); chemical substance - in men with mild and severe course was not observed at all, in 1 woman with mild course (5\%) and in 6 women with severe course (30\%);

insolation - in 3 men with mild (15\%) and 6 with severe (30\%), in 3 of 20 women with mild (15\%) and 7 with severe (35\%).

Attention was paid to the presence of bad habits, hereditary factors and comorbidities. The smoking habit was noted by 18 men with a mild course (90\%), 11 with a severe course (55\%), 6 women with a mild course (30\%), 1 woman with a severe course (40\%).

Hereditary SD was observed in only 3 men with severe course (15\%), 5 women with mild course (25\%) and 6 with severe course $(30 \%)$.

In the group of men with mild SD acne was detected in only one subject, in women of a similar group, a comparison of comorbidities was not detected at all. In severe SD, the following percentage of comorbidities was detected: in men, acne - in 13 people (65\%); rosacea - in 5 people (25 $\%)$; seborrheic keratosis - in 1 person (5\%); in women, acne - in 15 people (75\%); rosacea - in 5 people (25\%).

Typical clinical symptoms of seborrheic dermatitis are inflammation of the skin, peeling, which may be accompanied by itching, oiliness and dirt on the skin. The clinical picture varies depending on the location and severity of the disease [2, 10]. 
Itching was experienced by 14 men (70\%) and 10 women (50\%) with mild SD; 11 men (55\%) and 10 women (50\%) with severe dermatosis. Oily skin was noted by 18 men $(90$ $\%)$ and 17 women (85\%) with a mild course of the disease; 19 men $(95 \%)$ and all women (100\%) with severe SD. A feeling of dirt was present in 3 men (15\%) and 3 women (15 $\%)$ with mild SD; 12 men (60\%) and 17 women (85\%) with severe disease.

With SD on the skin of the face, head and torso, the pathological process is often presented in the form of limited erythematous foci of various sizes and contours. Fine-knot elements, peeling and infiltration can be noted. In the folds on the background of edema and erythema there is wetting with the formation of painful cracks [5, 17].

According to the localization of the pathological process, the subjects were distributed as follows:

on the head were observed in 9 men (45\%) and 2 women (10\%) with a mild course of the disease; 7 men (35\%) and 5 women (25\%) with severe SD;

on the face were observed in 19 men (95\%) and 16 women $(80 \%)$ with a mild course of the disease; in all men and women with severe SD;

on the trunk were observed in 1 man (5\%) and 1 woman (10\%) with a mild course of the disease; in 13 men (65\%) and 8 women (40\%) with severe SD.

In the presence of certain pathological elements, the distribution of patients was as follows:

erythematous spots were present in 9 men (45\%) and 2 women (10\%) with a mild course of the disease; 7 men (35 $\%)$ and 5 women (25\%) with severe SD;

erythematous plaques were present in 17 men (85\%) and 19 women (95\%) with a mild course of the disease; in 14 men (70\%) and 15 women (75\%) with severe SD;

sebaceous scales were present in 2 men (10\%) and absent in women with mild disease; in 10 men (50\%) and 12 women (60\%) with severe SD;

sebaceous scales-scabs were present in 16 men (80 $\%)$ and in all women with mild disease; in 6 men (30\%) and 6 women (30\%) with severe SD.

Dysfunction of the autonomic nervous system has a significant impact on the course of SD. With vagotonia, there is an increase in the secretion of sebum, sweating increases sharply and there is a stable red dermographism $[12,16]$.

By type of dermographism, the subjects were distributed as follows:

red dermographism was present in 10 men (50\%) and 12 women $(60 \%)$ with a mild course of the disease; in 10 men (50\%) and 11 women (55\%) with severe SD;

white dermographism was present in 5 men $(25 \%)$ and 2 women (10\%) with a mild course of the disease; 1 man (5 $\%)$ and 1 woman (5\%) with severe SD;

mixed dermographism was present in 5 men (25\%) and 6 women $(30 \%)$ in women with mild disease; in 9 men (45\%) and 8 women (40\%) with severe SD.

Kartamyshev's syndrome, pathognomonic SD, was observed in 2 men (10\%) and was not detected in women with mild disease; in 1 man (5\%) and was not detected in women with severe SD.

Thus, in the analysis of clinical and anamnestic data, it became known that the severity of SD increased with increasing length of disease and depended on the type of professional activity (more severe was in men whose work was physical and mixed, and in women - mental and mixed). In general, external factors had a significant impact on the manifestation or exacerbation of dermatosis, especially with regard to stress, temperature and humidity. The influence of such a modified factor as smoking and the unmodified one as heredity (in relation to the severe course) turned out to be significant. Along with SD, as the main dermatological disease, in its severe course, patients also had other dermatoses (acne, rosacea), which indicates the common pathogenetic links of these nosologies and a decrease in local immunity. The main complaints of the studied patients, regardless of the severity of SD were itching and oily skin, the feeling of dirt was more typical of patients with severe course. Severe SD, in contrast to mild, was most often accompanied by the localization of the pathological process on the torso, and rashes on the head and face were present in both groups of patients (except for women with mild SD, in whom rashes on the head were relatively rare). Each type of course had its own individual set of pathological elements. Thus, in mild cases, persons of both sexes were dominated by sebaceous scales, and in severe - sebaceous scales. Common skin manifestations of dermatosis for both types of course were erythematous spots and plaques. The predominance of red dermographism was noted in all groups of subjects, less often there was a mixed type of vegetative innervation and almost rarely - white dermographism.

The data obtained in our study can form the basis for the development of an algorithm for monitoring patients with generalized form of seborrheic dermatitis of varying severity.

\section{Conclusions and prospects for further development}

1. The study identified the most significant and common risk factors for seborrheic dermatitis in both groups of patients. These include: length of illness, working conditions, environment, bad habits and emotional state of the patient.

2. In mild and severe course there are characteristic and different clinical manifestations (subjective feelings and complaints, localization and type of rash elements, local manifestations of predominance of the tone of the autonomic nervous system), which allow timely assessment of the risk of generalization and timely appoint adequate therapy.

Further research is planned to assess the psychological characteristics of the personality of patients with SD depending on its severity, which will determine the psychological predictors and triggers of dermatosis. 


\section{List of references} allergens identified based on patch test results in patients with suspected contact dermatitis of the scalp. Skin appendage disorders, 3(1), 7-14. doi: 10.1159/000453530

[2] Amado, Y., Patiño-Uzcategui, A., Cepero de Garcia, M. C., Tabima, J., Motta, A., Cardenas, M., ... \& Celis, A. (2013). Seborrheic dermatitis: predisposing factors and ITS2 secondary structure for Malassezia phylogenic analysis. Medical mycology, 51(8), 868-875. doi: 10.3109/13693786.2013.820001

[3] Austin, B. A., Vu, A., Boothe, W. D., \& Stetson, C. L. (2020). Seborrheic dermatitis with massive facial hyperkeratosis resembling acquired ichthyosis. In Baylor University Medical Center Proceedings, 33(4), 594-595. Taylor \& Francis. doi: $10.1080 / 08998280.2020 .1779573$

[4] Clark, G. W., Pope, S. M., \& Jaboori, K. A. (2015). Diagnosis and treatment of seborrheic dermatitis. American family physician, 91(3), 185-190. PMID: 25822272 R. M., \& Staub, H. L. (2012). Scalp seborrheic dermatitis: prevalence and associated factors in male adolescents. International journal of dermatology, 51(1), 46-49. doi: 10.1111/ j.1365-4632.2011.04964.x

[6] Dessinioti, C., \& Katsambas, A. (2013). Seborrheic dermatitis: etiology, risk factors, and treatments:: facts and controversies. Clinics in dermatology, 31(4), 343-351. doi: 10.1016/ j.clindermatol.2013.01.001

[7] Errichetti, E., \& Stinco, G. (2016). Dermoscopy in general dermatology: a practical overview. Dermatology and therapy, 6(4), 471-507. doi: 10.1007/s13555-016-0141-6

[8] Kibar, M., Aktan, Ş., \& Bilgin, M. (2015). Dermoscopic findings in scalp psoriasis and seborrheic dermatitis; two new signs; signet ring vessel and hidden hair. Indian journal of dermatology, 60(1), 41. doi: $10.4103 / 0019-5154.147786$

[9] Lallas, A., Giacomel, J., Argenziano, G., Garcia-Garcia, B., Gonzalez-Fernandez, D., Zalaudek, I., \& Vazquez-Lopez, F. (2014). Dermoscopy in general dermatology: practical tips for the clinician. British Journal of Dermatology, 170(3), 514-526. doi: $10.1111 /$ bjd. 12685

[10] Lewallen, R., Clark, A., \& Feldman, S. R. (Eds.). (2014). Clinical
[1] Aleid, N. M., Fertig, R., Maddy, A., \& Tosti, A. (2017). Common

[5] de Avelar Breunig, J., de Almeida Jr, H. L., Duquia, R. P., Souza, P.

handbook of contact dermatitis: diagnosis and management by body region. CRC Press. ISBN-10: 9781482237177

[11] Mokos, Z. B., Kralj, M., Basta-Juzbasic, A., \& Jukic, I. L. (2012). Seborrheic dermatitis: an update. Acta Dermatovenerol Croat, 20(2), 98-104. PMID: 22726283

[12] Nobles, T., Muse, M. E., \& Schmieder, G. J. (2021). Dermatographism. In: StatPearls [Internet]. Treasure Island (FL): StatPearls Publishing; 2021 Jan. 19. PMID: 30285391

[13] Paniukova, S. V., Piruzyan, A. L., \& Korsunskaya, I. M. (2020). Себорейный дерматит: как помочь пациенту [Seborrheic dermatitis: how to help the patient]. Consilium Medicum, 22(7), 46-48. doi: 10.26442/20751753.2020.7.200314

[14] Paulino, L. C. (2017). New perspectives on dandruff and seborrheic dermatitis: lessons we learned from bacterial and fungal skin microbiota. European Journal of Dermatology, 27(1), 4-7. doi: 10.1684/ejd.2017.3038

[15] Polonskaya, A. S., Shatohina, E. A., \& Kruglova, L. S. (2020) Себорейный дерматит: современные представления об этиологии, патогенезе и подходах к лечению [Seborrheic dermatitis: modern ideas about the etiology, pathogenesis and approaches to treatment]. Клиническая дерматология и венерология - Clinical Dermatology and Venereology, 19(4), 451-458. doi: 10.17116/klinderma202019041451

[16] Taskapan, O., \& Harmanyeri, Y. (2006). Evaluation of patients with symptomatic dermographism. Journal of the European Academy of Dermatology and Venereology, 20(1), 58-62. doi: 10.1111/j.1468-3083.2005.01372.x

[17] Widaty, S., Pusponegoro, E. H., Rahmayunita, G., Astriningrum, R., Akhmad, A. M., Oktarina, C., ... \& Agustin, T. (2019). Applicability of trichoscopy in scalp seborrheic dermatitis. International journal of trichology, 11(2), 43-48. doi: 10.4103/ ijt.ijt_86_18

[18] Yusupova, L. A., Yunusova, E. I., Garaeva, Z. Sh., Mavlyutova, G. I., \& Panchenko, V. S. (2019). Себорейный дерматит: патогенетические аспекты, клинические формы и терапия больных [Seborrheic dermatitis: pathogenetic aspects, clinical forms and therapy of patients]. Лечащий врач - Therapist, 8, 48-51. ISSN: 2687-1181

\section{КЛІНІКО-АНАМНЕСТИЧНІ ОСОБЛИВОСТІ ЧОЛОВІКІВ І ЖІНОК, ХВОРИХ НА ГЕНЕРАЛІЗОВАНУ ЖИРНУ ФОРМУ СЕБОРЕЙНОГО ДЕРМАТИТУ РІЗНОГО СТУПЕНЯ ВАЖКОСТІ \\ Хасавнех Ахмад Раед}

Анотація. Незважаючи на поширеність себорейного дерматиту (СД), особливо серед людей молодого віку, достатньо мало відомо про його клініко-анамнестичні особливості у населення України. Для заповнення цієї прогалини необхідно провести дослідження достовірних даних, отриманих на вітчизняній вибірці працездатного віку. Метою дослідження $\epsilon$ вивчення клініко-анамнестичних особливостей чоловіків і жінок, хворих на генералізовану жирну фрорму себорейного дерматиту різного ступеня важкості. Було проведено обстеження 40 чоловіків і 40 жінок молодого віку (25-44 роки згідно вікової періодизації ВООЗ, 2015), хворих на генералізовану жирну форму себорейного дерматиту, на базі кафредри шкірних $і$ венеричних хвороб з курсом післядипломної освіти Вінницького національного медичного університету ім. М. І. Пирогова та Військово-медичного клінічного центру Центрального регіону. Ретроспективний аналіз включав оцінку паспортних, анамнестичних, клінічних даних. Діагноз СД встановлювали на підставі скарг досліджуваного, анамнезу життя і хвороби, огляду обличчя, волосистої частини голови, тулуба та кінцівок із оцінкою суб'єктивних і об'єктивних ознак захворювання. Статистичний аналіз проводився за допомогою ліцензійного пакету "Statistica 6.0". Встановлено, що тяжкість захворювання на СД збільшувалась при збільшенні стажу захворювання та залежала від роду професійної діяльності. Стрес, температура, вологість зовнішнього середовища, паління, спадковість зумовлюють прояв або загострення дерматозу. Акне і розацеа найчастіше супроводжують СД тяжкого перебігу. Свербіж і жирність шкіри, висипка на голові й обличчі, еритематозні плями і бляшки, переважання червоного дермографрізму відмічались при обох типах перебігу, а відчуття бруду, локалізація патологічних елементів на тулубі, сальні лусочки - лише при тяжкому. Таким чином, отримані в нашому дослідженні дані можуть лягти в основу розробки алгоритму моніторингу пацієнтів з генералізованою формою себорейного дерматиту різного ступеня важкості.

Ключові слова: себорейний дерматит, генералізована фрорма, клініко-анамнестичні дані, чоловіки, жінки, фрактори ризику. 